\title{
Ostatnia droga mieszkańców i pracowników warszawskiego Domu Sierot
}

Pisząc o ostatniej drodze Domu Sierot, podejmuję się zadania w pewnym sensie niewykonalnego. Niewykonalnego poznawczo, bo przy tej ilości świadectw, jakże sprzecznych i niespójnych, trudno ustalić wersję jedyną i prawdziwą. Mimo to postaram się, na tyle, na ile to możliwe, odtworzyć faktografię ostatniego pochodu Janusza Korczaka, personelu i dzieci z Domu Sierot. Analizę tę oprę na publikowanych dokumentach i wspomnieniach o ostatniej drodze, które ukazały się w wydawnictwach książkowych oraz w prasie. Ponadto uzupełnię ten obraz niepublikowanymi tekstami, do których dostęp jest możliwy w Ośrodku Dokumentacji i Badań Korczakianum. Chciałabym ustalić najbardziej prawdopodobny przebieg wydarzeń, aczkolwiek liczę się z ryzykiem, że nie będzie to pełny obraz. Wydaje mi się jednak, że już sama eliminacja wątków, które są bardziej faktami społecznymi niż historycznymi, będzie dość istotnym przyczynkiem do ustaleń. Nie chcę niczego udowadniać, cel zostanie osiągnięty, jeśli uda mi się stworzyć kompletny rejestr pytań i najbardziej prawdopodobnych odpowiedzi.

Aby nie pogubić się w dużej liczbie wątków i mieć narzędzia do ich porównywania, proponuję taki oto sposób analizy dokumentów. W pierwszej części artykułu drogę Janusza Korczaka z Siennej 16 / Śliskiej 9 na Umschlagplatz podzielę na pewne etapy, w obrębie których będę dokonywała porównań i interpretacji. I tak wyróżniam:

1. dziedziniec Domu, moment wyprowadzenia sierot;

2. drogę na Umschlagplatz (tu wykaz poszczególnych ulic, próba rekonstrukcji drogi przez getto);

3. sam Umschlagplatz, oczekiwanie na deportację;

4. zamykanie wagonów.

Następnie, już czysto spekulatywnie, bez świadectw naocznych obserwatorów, spróbuję naszkicować prawdopodobną wersję drogi z Umschlagplatz do stacji Treblinka. Będę się przy tym opierać na opracowaniach naukowych, wspomnieniach zbiegów z Treblinki, a także zatrudnionych tam pracowników kolei.

Już na wstępie mamy problem z podstawowymi ustaleniami, a mianowicie $\mathrm{z}$ datą wyprowadzenia sierocińca Janusza Korczaka. We wspomnieniach pojawia się naj- 
częściej data 5 sierpnia 1942, zaraz potem data 6, a także 12 i 3 sierpnia ${ }^{1}$. Tę ostatnią można odrzucić od razu, jako że ostatni zapisek w Pamiętniku doktora Korczaka jest datowany na 4 sierpnia 1942, co całkowicie wyklucza możliwość wyprowadzenia Domu Sierot dzień wcześniej. Datę 12 sierpnia można by zaś tłumaczyć w następujący sposób: człowiek, który widział pochód, nie zapamiętał dokładnej daty, a jedynie dzień tygodnia i to, że działo się to jakoś na początku miesiąca. Jest zrozumiałe, że po doświadczeniu sytuacji granicznej, po latach, nie był w stanie dokładnie przypomnieć sobie wszystkich szczegółów i być może na zasadzie dedukcji próbował dochodzić do pewnych ustaleń. Wiedział, że była to środa mniej więcej na początku sierpnia, stąd 12, druga środa sierpnia 1942. Data ta jest jednak wskazywana tak rzadko, że nie ma sensu upierać się przy jej prawdopodobieństwie, tym bardziej że historia getta warszawskiego także z trudem ją dopuszcza. Jedyne, co może być dla nas istotne w tym wspomnieniu, to zasugerowany dzień tygodnia. Można więc uznać za prawdopodobne zarejestrowanie okoliczności, ewentualnie jakichś wydarzeń towarzyszących. O ile zatem przyjęcie daty 12 sierpnia jest wykluczone, o tyle wskazanie, że to była środa, może być argumentem za dniem 5 sierpnia. Czy jednak na pewno? Środa nie jest zbyt charakterystycznym dniem tygodnia, nie jest to ani szabat, ani niedziela, ani żaden dzień w ich bezpośrednim sąsiedztwie.

Można zatem przyjąć, że wydarzenie to miało miejsce albo 5, albo 6 sierpnia, czyli w środę lub czwartek. Rzetelny kronikarz getta, Abraham Lewin, 7 sierpnia pisze w swoim dzienniku: „Wczorajszy dzień był wstrząsający. Z małego getta zabrali bardzo wielu ludzi. [...] Uprowadzono dzieci z sierocińca dra Korczaka, z doktorem na czele. Dwieście dzieci”3. Ale Lewin pochodu nie widział. Zostało mu to przekazane albo od razu przez naocznego świadka, albo z kolejnych ust, gdy smutna wiadomość zaczęła krążyć po getcie i żyć własnym życiem.

5 sierpnia było ciepło, ulice zalane były słońcem, natomiast 6 pogoda już nieco się popsuła, a temperatura powietrza spadła ${ }^{4}$. To samo zapisał w swoim pamiętniku Franciszek Wyszyński, który notował stan pogody w Warszawie w czasie okupacji. Napisał mianowicie: „4 VIII wtorek. Z rana pochmurno i zimny wiatr. [...] 5 VIII środa. Ciepło, można było wyjść bez palta [...]. 6 VIII czwartek. Chłodnawo”5. Ponadto w informacji z Ministerstwa Infrastruktury i Gospodarki Wodnej wynika, że 6 były w Warszawie przelotne deszcze, o których w relacjach nikt nie wspomina. W większości wspomnień pojawia się dość wyraźny wątek upalnego sierpnia, który może sugerować, że jednak bardziej prawdopodobna jest wcześniejsza data, to

${ }^{1}$ M. B. [Antoni Szymanowski], Likwidacja getta warszawskiego (Reportaż), Komisja Propagandy BIP, Warszawa 1942, s. 28.

2 J. Korczak, Pamiętnik [w:] idem, Pisma wybrane, t. 4, Warszawa 1986, s. 400.

${ }^{3}$ A. Lewin, Dziennik z warszawskiego getta, zapis z 7 VIII 1942, cyt. za: M. Falkowska, Myśl pedagogiczna Janusza Korczaka, Warszawa 1983, s. 286.

${ }^{4}$ Por. B. Engelking, J. Leociak, Getto warszawskie. Przewodnik po nieistniejącym mieście, Warszawa 2001, s. 677-678.

${ }^{5}$ F. Wyszyński, Dzienniki z lat 1941-1944, oprac. J. Grabowski, Z.R. Grabowski, Warszawa 2007, s. 179-180. 
jest 5. I właśnie tak Nachum Remba, pracownik Umschlagplatzu, który prawdopodobnie jako ostatni rozmawiał z Korczakiem, opisał okoliczności tego wydarzenia: „Był strasznie upalny dzień”. Irena Sendlerowa dodaje: „Zapamiętałam 6 sierpnia 1942 jako dzień szalenie upalny"7.

Można by rozważać, jakiego rodzaju informacje mogą zostać w pamięci bardziej nienaruszone. Jak już wcześniej pisałam, wydaje mi się, że łatwiej pomylić datę niż wspomnienia sensoryczne. O tym, że dzień był ciepły, świadczyć może także kwestia wody, o której wspomina Ringelblum. Pisze on mianowicie: „Jak przystało na doktora Korczaka, zaopatrzył on i tym razem swe dzieci w kilka beczek wody na drogę"8.

I jeszcze jedno: Adolf Berman pisze, że Dom Sierot Janusza Korczaka zaprowadzono na Umschlagplatz wraz z innymi sierocińcami i internatami z małego getta. „Jednym z pierwszych wywiezionych internatów był »Dom Sierot « Janusza Korczaka. W czasie okrutnej blokady szeregu ulic w »małym getcie« wypędzono dzieci z ich prowizorycznego lokalu (Dom Sierot musiał trzy razy przeprowadzać się) i razem z wielotysięczną rzeszą ludzką pognano na Umschlagplatz. [...] Tego samego dnia wywieziono wzorowy internat dla chłopców przy ul. Twardej 7 z jego ofiarnymi kierownikami Dąbrowskim i Szternfeldem na czele, oraz schronisko dla dziewcząt przy ulicy Śliskiej 28, z jego zasłużoną kierowniczką Broniatowską na czele. Cały personel również i tych dwóch zakładów poszedł na śmierć razem z dziećmi”"

Autorzy Przewodnika po warszawskim getcie łączą datę 5 sierpnia 1942 r. z wyprowadzeniem m.in sierocińca z Twardej 77 i Śliskiej $28^{10}$, a więc dokładnie tych dwóch, o których mówi Berman. Jeśli połączyć ten fakt ze wspomnieniami Franciszka Ząbeckiego - pracownika kolei w Treblince, to okaże się, że Korczak mógł być wyprowadzony wraz z nimi. Ząbecki pisze: „Było to 7 lub 8 sierpnia 1942 r., a więc pierwsze tygodnie mordów w Treblince. Transporty z »przesiedleńcami« stały na stacji przez całą noc. W transporcie z Warszawy znajdowało się kilka wagonów załadowanych młodzieżą. Byli to chłopcy [podkreślenie moje - A. W.]. Wśród ogólnego płaczu, krzyku i lamentu z jednego wagonu dochodził śpiew mężczyzny, śpiewającego polską pieśń religijną: »Kto się w opiekę odda Panu swemu«. Wychodząc tej nocy dość często celem przepuszczenia transportów wojskowych, widziałem, jak mimo strzałów oddawanych przez konwojentów do uciekających, pojedyncze osoby przemykały się na drugą stronę pociągu. Na stacji, wzdłuż torów stała ułożona cegła w wysokich pryzmach do budowy nowego budynku stacyjnego. Stamtąd usłyszałem ściszony męski głos: »Panie kolejarz! Panie kolejarz! Pomóż mi pan wydostać się stąd. Powiedz pan, którędy trzeba iść dalej«. Przekręciłem dopływ

${ }^{6}$ E. Ringelblum, Kronika getta warszawskiego wrzesień 1939 - styczeń 1943, red. A. Eisenbach, Warszawa 1983, s. 607.

${ }^{7}$ Rozmowa z Ireną Sendlerową, „Polityka” 1997, nr 21, s. 94.

${ }^{8}$ E. Ringelblum, op. cit., s. 454.

${ }^{9}$ A. Berman, O losie dzieci z zakładów opiekuńczych $w$ getcie warszawskim, „Biuletyn ŻIH” 1958, nr 28, s. 73-74.

${ }^{10}$ Por. B. Engelking, J. Leociak, op. cit., s. 677. 
wody do latarki karbidowej, aby zmniejszyć światło, odwróciłem latarkę, aby nie oświetlać miejsca, do którego szedłem, a następnie postawiłem latarkę przy słupie na peronie i wszedłem między cegły. Był tam młody Żyd, rabin, z charakterystycznymi bokobrodami pejsami. [...] Powiedział mi jednocześnie, że $\mathrm{w}$ tym transporcie jedzie wychowawca i przyjaciel młodzieży, wielki pedagog i pisarz z Warszawy (prawdopodobnie był to Janusz Korczak), którego znał od dawna, z którym od kilkunastu tygodni wspólnie modlili się katolicy, gdyż jak mówił ów pedagog, wszyscy ludzie mają wspólnego jedynego Boga"11.

Data podana przez Ząbeckiego niczego nie uściśla, ale fakt, że wagony były pełne chłopców, pozwala na przypuszczenie, że chodzi tu o internaty i sierocińce męskie, wyprowadzone z małego getta. Charakterystyka Korczaka, którą daje Ząbecki, także nie jest zbyt dokładna, niemniej pasuje do jego osoby. O kim innym mógłby mówić? Wątpliwość jednak wzbudza stwierdzenie, że od kilkunastu tygodni modlili się z nim chrześcijanie, bo jeśli tak, to kiedy i w jakich okolicznościach? Korczak, mimo swojej otwartości i przyjaźni z katolikami (m.in. z Marią Czapską), nie miał chyba w getcie zbyt wiele czasu, by uczestniczyć w zbiorowych modlitwach...

Należy wziąć jednak pod uwagę jeszcze jeden dość istotny aspekt, a mianowicie kwestię związaną z Pamiętnikiem. Ostatni zapis nosi datę 4 sierpnia 1942 (Korczak pisywał go w nocy, więc najpewniej jest to zapis z nocy z 3 na 4 sierpnia), a ostatnie zapiski w Pamiętniku prowadzone są dość regularnie, byłby to zatem pośredni dowód na to, że Korczak został wyprowadzony już 5 sierpnia. Z drugiej jednak strony, zachowany oryginał jest w bardzo dobrym stanie, kartki nie są wygniecione, a ich wygląd wskazuje na to, że musiały zostać przed wyniesieniem z getta dobrze do tego przygotowane i zabezpieczone ${ }^{12}$. Korczak ponadto pisał ręcznie, jego zapiski przepisywał Henryk Azrylewicz, musiał więc mieć czas na to, by się tym zająć, tym bardziej że zapis z 4 sierpnia jest dość obszerny. Jest zatem wielce prawdopodobne, że to właśnie 4 sierpnia w ciągu dnia Korczak czynił starania, by przekazać Pamiętnik na stronę ,aryjską”, musiał więc być jeszcze wtedy w getcie. Według relacji Igora Newerlego, Korczak zaczął pisać Pamiętnik w 1940 r., potem przerwał pisanie. Od maja 1942 pisał już systematycznie. Maszynopis Pamiętnika doręczony został Newerlemu już po wywiezieniu mieszkańców Domu Sierot do Treblinki. Dokument ten, przekazany Marynie Falskiej przez żonę Newerlego, zamurował w gmachu Naszego Domu na Bielanach Władysław Cichosz. Po wojnie ten sam pracownik Naszego Domu wydobył przechowywany Pamiętnik. Otrzymał go ponownie Igor Newerly po swoim powrocie do kraju z obozów koncentracyjnych i złożył w Archiwum Korczakowskim, z adnotacją, że jest to dokument otrzymany od Marii Podwysockiej ${ }^{13}$. Dzieje Pamiętnika wymagają jednak jeszcze dokładnego zbadania.

${ }^{11}$ F. Ząbecki, Wspomnienia dawne i nowe, Warszawa 1977, s. 51-52.

12 Najprawdopodobniej wraz z innymi materiałami z Domu Sierot, które odnalazły się dopiero po latach i opublikowane są w książce: Nowe źródła. Janusz Korczak w getcie, Warszawa 1992.

${ }^{13}$ Por. J. Korczak, Pisma wybrane, t. 4, Warszawa 1978, s. 399. 
Nie wydaje mi się, aby obecnie można było rozstrzygnąć na pewno, którego dnia Korczak wraz z dziećmi i personelem Domu Sierot został pognany na Umschlagplatz, choć moim zdaniem więcej przesłanek wskazuje na datę 5 sierpnia.

Pisząc o czasie, warto także zastanowić się, jak długo trwała ta droga. Jak wielu godzin potrzeba było Korczakowi, dzieciom i personelowi, by dojść z Siennej na Umschlagplatz, jak długo musieli czekać tam na wagon i jak długo mogła trwać podróż do Treblinki? Żeby wyczerpująco odpowiedzieć na to pytanie, trzeba z możliwie największą dokładnością określić wszelkie parametry i okoliczności drogi, jaka dzieliła Dom Sierot na Śliskiej od Umschlagplatzu. Na początek kilka podstawowych ustaleń. Pewne są dwa punkty: początek drogi i jej koniec, czyli Sienna 16 i stacja placu przeładunkowego przy ulicy Stawki. Możemy także przyjąć, że niewątpliwie musieli przejść przez most na Chłodnej, jako że był to jedyny sposób dostania się z małego getta do dużego. Trasę pomiędzy tymi trzema punktami postaram się zrekonstruować na podstawie relacji, analizując te fragmenty, w których autorzy wyraźnie mówią o swoim położeniu topograficznym. I tak:

- Luba Blum-Bielicka: plac Grzybowski;

- Adina Blady-Szwajger: szpital chirurgiczny, róg Leszna i Żelaznej;

- Irena Sendlerowa: ulica Leszno;

- Mary Berg: ulica Gęsia, okno Pawiaka (Zaznaczam tutaj istnienie tej relacji, ale nie będę z niej korzystać, bo niestety nic nie przemawia za jej prawdziwością. Mary Berg prawdopodobnie widziała kogoś innego, albo może nawet nie widziała, tylko słyszała od kogoś.);

- Władka Meed: ulica Gęsia 13;

- Kalman Szapiro: ulica Zamenhofa.

Daje to ogólny zarys trasy, którą szedł Korczak z dziećmi, można zatem podjąć próbę zmierzenia jej i podania przybliżonego czasu przemarszu. Zakładając, że dzieci szły bez postojów, droga ta mogła trwać od dwóch do czterech godzin. Biorąc jednak pod uwagę wszelkie możliwe okoliczności, należy założyć, że mogła znacznie się wydłużyć. Mówiąc „wszelkie możliwe okoliczności”, mam na myśli tłum wysiedlanych na ulicach, minuty oczekiwania, przystanek na placu Grzybowskim, o którym pisze Blum-Bielicka oraz trudność przejścia przez most na Chłodnej. Irena Sendlerowa mówi, że tego dnia: „Na ulicach byli nieliczni przechodnie. Każdy podążał w swoim kierunku. Nikt nie przystawał. Ludzie się bali”14.

Ulice prawdopodobnie były blokowane, zamykano poszczególne odcinki, by w miarę sprawnie przeprowadzić przez nie pochód na Umschlagplatz. Ale i tak przejście przez ulice miasta z dwoma setkami dzieci na pewno nie było łatwe.

Zanim przejdę do szczegółowej analizy marszu, chciałabym jeszcze zwrócić uwagę na inne zagadnienie, a mianowicie: czy mieszkańcy i pracownicy Domu Sierot mogli być przygotowani do tej ostatniej drogi? To jednak zbyt ogólne pytanie, należy zatem rozbić je na dwa bardziej szczegółowe i dotyczące w gruncie rzeczy nieco innych problemów. Zatem: czy wiedziano o planowanej deportacji Domu Sie-

\footnotetext{
${ }^{14}$ Rozmowa z Ireną Sendlerową, „Polityka” 1997, nr 21, s. 94.
} 
rot i czy wiadomo było, dokąd wywożeni są Żydzi? I czy przemyślano wcześniej scenariusz tego pochodu? Czy jakoś przygotowano do tego dzieci?

Jest wielce prawdopodobne, że Korczak i personel zdawali sobie sprawę z planowanych wywózek (nie przesądzamy na razie, czy brali pod uwagę obóz zagłady czy wyjazd na roboty, jak oficjalnie deklarował Judenrat) i mieli świadomość, że przyjdzie czas, kiedy Dom Sierot na Siennej 16 będzie trzeba nagle, w pośpiechu, opuścić. Podczas toczonych w gronie wychowawców rozmów o losie dzieci nie podjęto decyzji o ich oddaniu rodzinom czy pozwoleniu na samodzielne radzenie sobie na ulicach getta. Można przypuszczać, że już wtedy poczynione zostały pewne materialne i psychologiczne przygotowania do ewentualnej przeprowadzki czy przesiedlenia. Pisząc: materialne, mam na myśli spakowanie plecaków, przygotowanie ubrań. Trzeba pamiętać o jeszcze jednej, ważnej kwestii, a mianowicie o perfekcji Korczaka, jego dbałości o szczegóły i o bezpieczeństwo dzieci. Jeszcze przed wojną napisał tekst pt. Spacer, w którym dał kilka konkretnych wskazówek dla wychowawców, którzy chcą wybrać się z dziećmi na wycieczkę po mieście. Pisze między innymi: „1) Należy nauczyć dzieci chodzić parami. [...] 2) Należy przyzwyczaić dzieci do szybkiego rozbiegania się i zbierania na umówiony znak. [...] 7) Należy pamiętać, że gromada, szczególnie dzieci, utrudnia wychowawcy zadanie. Dlatego należy tak urządzić, żeby dzieci przeszkadzały jak najmniej, to znaczy nie pchały się, nie krzyczały za głośno, nie drażniły niepożądaną odzieżą. Przyzwoity wygląd gromady robi dobre wrażenie, co prawda budzi też zawiść. [...] 9) Należy przewidzieć wszystkie możliwe przypadki, które mogą się zdarzyć po drodze i wyjaśnić dzieciom, jak powinny zachowywać się w takich razach. Dziwnie to zabrzmi, jeśli wychowawca będzie zarzucał dzieciom, że czegoś nie wiedzą - przecież nie mają doświadczenia”15.

Istnieją wspomnienia o tym, że gdy Korczak wraz z dziećmi przeprowadzał się z Krochmalnej do getta, po drodze głośno śpiewano „Choć burza huczy wkoło nas...”" Wspomina to Hanna Mortkowicz-Olczakowa, przyjaciółka Korczaka, au-

${ }^{15}$ Wydrukowane w języku jidysz w: „Dos Kind”, 1924, nr 4, s. 26-30, oryginał polski nie zachował się; teraz przygotowywane do publikacji w: Janusz Korczak, Dzieła, t. 13.

${ }^{16}$ Por. H. Rudniańska, Korczak, Tokarzewski i my, Kraków 2005, s. 22. Warto przyjrzeć się słowom tej dumnej pieśni (autorem tekstu, napisanego w latach dziewięćdziesiątych XIX w. do muzyki Franciszka Schuberta, jest ks. Paweł Sikora), która w czasie przeprowadzki do getta pozwalała mieszkańcom i pracownikom Domu Sierot wierzyć w przyszłość. Brzmią one następująco:

Choć burza huczy wkoło nas,

Do góry wznieśmy skroń!

Nie straszny dla nas burzy czas,

Boć silną przecie mamy dłoń!

Weselmy, bracia, się,

Choć wicher żagle rwie!

Kto pracą święci każdy dzień,

Ten smutku nie zna, nie! 
torka wielu książek o nim. Pisze: „Doktor i pani Stefa, z właściwym im spokojem i umiejętnością organizacyjną, przygotowywali przeprowadzkę [do getta - A. W.]. Szykowano się do niej sprawnie, umiejętnie i w takiej godnej ciszy, jak gdyby chodziło tu o coroczny wyjazd do Gocławka, z którego wróci się wesoło po wakacjach. Z moich ostatnich rozmów z Doktorem pamiętam i inne projekty. Jak zawsze, kiedy był dotknięty i wzburzony wewnętrznie, chciał i teraz zadrwić z siebie, z Niemców, z tragicznego przymusu. Projektował przeprowadzkę jako wielką operę-buffo, groteskowy pochód przez miasto, w którym korowód dzieci miałby nieść na nowe locum: lampy, klatki z ptaszkami i... nocniki..."17.

Korczak był mistrzem ceremonii, a wiedząc, że ceremonia może usprawnić przebieg rzeczy, a przede wszystkim zmniejszyć strach, był w stanie doprowadzić ją do granic groteski. Dzieci nie powinny były wiedzieć, dokąd idą i co je czeka. Korczak nie chciał dopuścić atmosfery grozy, wiedział, że ona w niczym nie pomoże, a tylko przedłuży i zintensyfikuje strach. Być może okłamał dzieci, być może kłamał do końca... Helena Merenholc, bliska znajoma Korczaka i Stefanii Wilczyńskiej, wspomina słowa: „Nie - mówili ze Stefą - dzieci nic nie wiedzą, robimy wszystko, aby było spokojnie bez paniki” ${ }^{18}$.

Czas jednak, by podjąć próbę odtworzenia ich drogi. Jak dzieci szły, jak mogły być ubrane, dlaczego tak bardzo rzucały się w oczy? Zacznijmy od chwili wyprowadzania dzieci z Domu Sierot.

Odbywało się to w godzinach porannych, na co wskazuje wspomnienie Anny Margolisowej, która pisze o swoich pierwszych wrażeniach po wejściu do Domu Sierot: „Drzwi były otwarte, kawa się gotowała, łóżka nie zasłane. Wszędzie rozgardiasz"19. Świadczy o tym także opis wyprowadzenia dzieci sporządzony przez Marka Rudnickiego: „Gdy poszedłem rano [...] około dziesiątej, pod dom na Siennej 16, dzieci już stały na chodniku uformowane w czwórki”20. I jeszcze wspomnienie Ireny Sendlerowej ${ }^{21}$, która regularnie chodziła do getta, by wyprowadzać stamtąd żydowskie dzieci. Mówi ona: „Zwykle chodziłam do getta po południu, po swojej normalnej pracy, lecz tego dnia byłam przed południem. Szłam Lesznem do Żelaznej, kierując się do wyjścia między Chłodną a Żelazną, gdzie była wacha, brama,

Choć słońce skryje chmury cień,

My w lepszą przyszłość patrzmy się!

Weselmy, bracia, się,

Choć wicher żagle rwie!

${ }^{17}$ H. Mortkowicz-Olczakowa, Janusz Korczak, Warszawa 1978, s. 226-227.

${ }_{18}$ Ośrodek Dokumentacji i Badań Korczakianum, teczka 0820, Relacja Heleny Merenholc, spisana przez Matyldę Temkin w 1958 roku.

${ }^{19}$ A. Margolisowa, W ostatnim roku [w:] Wspomnienia o Januszu Korczaku, oprac. L. Barszczewska, B. Milewicz, Warszawa 1989, s. 336.

${ }^{20}$ Rozmowa z M. Rudnickim, „Tygodnik Powszechny” 1988, nr 45, s. 1-2.

${ }^{21}$ Mam poważne wątpliwości, gdy czytam tę relację. Wydaje się bowiem wręcz nieprawdopodobne, że Irena Sendlerowa mogła znaleźć się w getcie w czasie trwania Wielkiej Akcji i chodzić po najbardziej ruchliwych ulicach. 
przez którą miałam wyjść z getta. Pochód Korczaka spotkałam, kiedy z Żelaznej skręcali w Leszno"22.

Dzieci wyszły z Domu Sierot prawdopodobniegłównym wyjściem przy Siennej 16 i zostały skierowane w stronę placu Grzybowskiego, jako że to właśnie tam był punkt zbiorczy osób przeznaczonych do wysiedlenia. Dysponujemy relacją Luby Blum-Bielickiej, która w tym samym czasie co Korczak była na placu Grzybowskim. Tego samego dnia, co dzieci Korczaka, zostały wyprowadzone dziewczęta ze Szkoły Pielęgniarskiej, która mieściła się przy ulicy Mariańskiej $2^{23}$. Blum-Bielicka pisze: „22 lipca 1942 r. rozpoczęła się w Warszawie akcja eksterminacyjna ludności żydowskiej. Zaczęli wywozić przede wszystkim z domów noclegowych, gdzie mieszkała ludność przeniesiona $z$ innych miast. Po dwu tygodniach, 6 sierpnia przyszła kolej na nas. Wszystkie mieszkanki naszego internatu wyprowadzili SS-mani na plac Grzybowski. Uczennice były w mundurach pielęgniarek. Cały personel administracyjny też otrzymał mundury. Na placu było blisko 40000 osób, cała ludność małego getta, był tu też Janusz Korczak ze swoimi schludnie ubranymi dziećmi. Na skutek kłamliwej propagandy hitlerowskiej ludność żydowska wierzyła, że jest to wysiedlenie na roboty, a nie na śmierć. Janusz Korczak zapewniał mnie w rozmowie przeprowadzonej w godzinach rannych na placu Grzybowskim, że »wystarał się dla swoich dzieci o specjalny wagon«"24.

Aby dojść z Siennej 16 na plac Grzybowski, Korczak wraz z dziećmi prawdopodobnie szedł ulicami: Sienną, Sosnową, Śliską, Komitetową, Pańską, Mariańską, a potem Twardą już prosto do placu Grzybowskiego. Co działo się dalej? Po postoju i zgromadzeniu wszystkich przeznaczonych tego dnia do wywózki pochód ruszył w stronę Umschlagplatzu. W okolicach placu Grzybowskiego widziała Korczaka także Bronisława Frolman, której tego dnia udało się przekupić Ukraińca zegarkiem i wydostać z łapanki. Wspomina: „Wskoczyliśmy szybko do jakiejś bramy i czekaliśmy na przejście szeregów jeszcze parę chwil, aż usłyszeliśmy wznowiony ruch na ulicach. Wówczas odważyliśmy się wyjść i pierwszą napotkaną rikszą wróciliśmy do domu. Przejeżdżając przez Plac Grzybowski, napotkaliśmy maszerujący sierociniec z Doktorem Korczakiem na czele. Zdumienie i przerażenie odebrało mi mowę"25.

Żeby przedostać się z małego getta do dużego, trzeba było przejść mostem nad ulicą Chłodną. Z placu Grzybowskiego zatem szli najprawdopodobniej Twardą, Ciepłą, Grzybowską do Żelaznej. Dalej Żelazną, mostem nad Chłodną, skręcając potem w Leszno. Kolejnym świadkiem pochodu Korczaka była Adina Blady-Szwajger, która opowiadała o tym Ance Grupińskiej, mówiąc, że widziała go z okna szpitala ${ }^{26}$,

${ }^{22}$ Rozmowa z I. Sendlerową, „Polityka” 1997, nr 21, s. 94.

${ }^{23}$ Por. A. Margolis-Edelman, Ala z elementarza, Londyn 1994, s. 47.

${ }^{24}$ L. Blum-Bielicka, Szkoła Pielęgniarstwa w Warszawie, „Biuletyn ŻIH” 1961, nr 40, s. 73.

${ }^{25}$ B. Frolman, Widziałam Janusza Korczaka w jego ostatniej drodze, „Nowiny Kurier” 30 XI 1978, kopia w Ośrodku Dokumentacji i Badań Korczakianum, teczka 0460.

${ }^{26}$ Okna szpitala wychodziły na ulicę Żelazną, zatem trudno byłoby Adinie Blady-Szwajger dostrzec pochód skręcający z Żelaznej w Leszno. Byłoby to możliwe jedynie, gdyby stała przy oknie, które było stosunkowo blisko ulicy Leszno. 
w którym wówczas pracowała. „Szpital był na rogu Leszna. Okno, przy którym staliśmy wychodziło na Żelazną. Dzieci szły Żelazną w stronę Nowolipek. Tak, że widzieliśmy je na małym odcinku. I koniec. Myśmy nie mogli się nawet ruszyć przy tym oknie. A oni po prostu defilowali przed nami”27.

W innym miejscu Adina Blady-Szwajger pisze, wskazując przy tym na niemożność zapamiętania konkretnej daty: „A potem jeszcze raz staliśmy tak we framudze okiennej i patrzyliśmy, jak Żelazną w stronę Nowolipek idzie Korczak ze swoimi dziećmi. Podobno to było 6 sierpnia, ale ja tego nie pamiętam, bo myśmy dni nie liczyli”28. Ta wypowiedź wpisuje się w postawioną wcześniej tezę: daty podawane przez świadków nie są całkowicie pewne, lepiej samodzielnie je ustalać na podstawie okoliczności.

Chwilę potem marsz Domu Sierot zobaczyła Irena Sendlerowa, która w ten sposób to opisuje: „Widziałam ich, kiedy z ulicy Żelaznej skręcali w ulicę Leszno. [...] Cały ten orszak kroczył czwórkami, sprężyście, miarowo, dostojnie na Umschlagplatz - na plac śmierci"29.

Mniej więcej w tym samym punkcie widział Korczaka Stanisław Szulfried, który był wówczas w urzędzie na rogu ulicy Leszno i Żelaznej. Pisze: „Na początku sierpnia 1942 r. byłem w żydowskim Arbeitsamcie przy ul. Leszno róg Żelaznej. [...] Po kilku minutach usłyszeliśmy, my, interesanci i urzędnicy z sali, jakieś dziwne odgłosy z ulicy. Dotarłem wraz z innymi obecnymi na sali do okna i rozpostarł się przed nami niesamowity widok pochodu ludzi i dzieci prowadzonych na Umschlagplatz. Z obydwu stron było widać konwojentów - »szaulisów« i policjantów żydowskich... W środku tego makabrycznego pochodu wiele małych, drobnych, wychudzonych dzieci w sukienkach, pod opieką szczupłej, wysokiej wychowawczyni. Poznałem w niej Stefanię Wilczyńską. W środku tego pochodu dzieci szedł Janusz Korczak, trzymając jedno dziecko na ręku i prowadząc drugie za rękę. Szedł ze swoimi dziećmi. Był to ich ostatni marsz, ostatni warszawski spacer. Uśmiechał się do swoich dzieci - on kochający je całą swą duszą - i one ufnie spozierały na niego. Dodawał dzieciom otuchy »oto jedziemy na wycieczkę do lasu«. To przecież Pan Doktór jest z nimi, więc nic złego nie może się im przytrafić.

Były to ostatnie chwile, gdy widziałem Go... Były to chwile zgrozy, pełne goryczy... chwile, które wołały o pomstę" ${ }^{30}$.

Z tego miejsca mogli iść ulicami Karmelicką i Dzielną do Zamenhofa albo skręcić w Nowolipki i potem w Zamenhofa. Tę pierwszą opcję potwierdza Marek Rudnicki,

${ }^{27}$ Tak naprawdę - w 1942 roku wyszłam z domu i nigdy do niego nie powróciłam. Rozmowa z Adiną Blady-Szwajger [w:] A. Grupińska, Ciagle po kole. Rozmowy z żotnierzami getta warszawskiego, Warszawa 2000, s. 195.

${ }^{28}$ A. Blady-Szwajger, I więcej nic nie pamiętam, Warszawa 1994, s. 41.

${ }^{29}$ Wspomnienie I. Sendlerowej, spisane w styczniu-lutym 1997, oryginał przekazany prof. T. Szarocie, tenże oryginał w Archiwum Korczakowskim w Beit Lohamei Haghetaot, sygn. 5059/KR VII/168, kopia w Ośrodku Dokumentacji i Badań Korczakianum.

${ }^{30}$ Ośrodek Dokumentacji i Badań Korczakianum, teczka 0461, Relacja Stanisława Szulfrieda. 
który zapewnia, że szedł z Korczakiem od Siennej do bramki Umschlagu. Mówi: „Ta droga z Siennej przez Leszno, Karmelicką, Dzielną, Zamenhofa do ulicy Stawki wydawała się bardzo długa"31.

W tym momencie warto także zwrócić uwagę na meandryczność drogi z Siennej na Umschlagplatz. Trasę tę można było pokonać prawdopodobnie w dużo krótszym czasie, bez zmęczenia, oczekiwania, przepuszczania innych. Ulice, jak już wspomniałam, podczas wysiedlenia były blokowane, aby umożliwić bezkolizyjne przejście i jednocześnie uniemożliwić ucieczkę prowadzonym. Dochodziła jednak do tego absurdalność topograficzna warszawskiego getta; nierzadko trzeba było przejść kilkadziesiąt metrów, by dostać się na drugą stronę ulicy. Wędrówka w tym labiryncie trwała bardzo długo.

Kolejnym punktem, z którego obserwowany był Korczak wraz ze swoim pochodem, jest schron przy ulicy Gęsiej 13, a obserwatorką - Władka Meed (Feigele Peltel-Międzyrzecki), która wówczas się tam ukrywała. Pisze ona: „Pamiętam z mojej kryjówki na Gęsiej 13, widziałam marsz sierocińca Janusza Korczaka. Ten wybitny pedagog i wychowawca pracował niestrudzenie na rzecz sierot z getta. Teraz, w eskorcie niemieckich żołnierzy, stary doktor prowadził swoich wychowanków na spotkanie śmierci. Dzieci szły w milczeniu, niosąc koce i trzymając się za ręce. Tego samego dnia, 5 sierpnia, Niemcy »zlikwidowali« również wszystkie pozostałe instytucje opieki nad dziećmi”32.

Władka Meed podaje także inne szczegóły tego obrazu: „W pewnej chwili usłyszeliśmy gdzieś w oddali odgłos kroków. Zza zasłoniętych okien mogliśmy wyjrzeć na zewnątrz. Znajdowaliśmy się w narożnym budynku na skrzyżowaniu ulic Gęsiej i Zamenhofa, skąd wiodła droga na Umschlagplatz. To wtedy zobaczyłam Janusza Korczaka, słynnego doktora, wychowawcę i pisarza, jak szedł wraz ze swoimi wychowankami z domu sierot. Niektóre dzieci rozglądały się wokół siebie. Pochód posuwał się w otoczeniu Niemców z postawionymi na sztorc bagnetami. Wszyscy, wśród nich i Janusz Korczak, zmierzali w stronę pociągów towarowych"33.

Mamy do dyspozycji jeszcze jedną, dość lakoniczną relację - list Kalmana Szapiro do redakcji „Polityki”, w którym autor pisze: „Widziałem, jak Janusz Korczak szedł ulicą Zamenhofa na czele dzieci z Domu Sierot podczas tragicznego przemarszu przez getto. Nosił on jedno dziecko na ręku, a drugie trzymał za rękę"34.

A potem szli już prosto na Umschlagplatz, by wejść na jego teren od strony ulicy Dzikiej...

Jak jednak przebiegał ten marsz? Co robił Korczak, Stefania Wilczyńska, dzieci? Marek Rudnicki tak pisze o swoich wrażeniach: „Atmosferę przenikał jakiś ogromny bezwład, automatyzm, apatia. Nie było widocznego poruszenia, że to Korczak

\footnotetext{
${ }^{31}$ Rozmowa z M. Rudnickim, loc. cit., s. 1-2.

${ }^{32}$ W. Meed, Po obu stronach muru, Warszawa 2003, s. 66.

${ }^{33}$ Ibidem, s. 67.

${ }^{34}$ Kalman Szapiro, list do redakcji „Polityki” 1972, nr 47, s. 1. Niedawno rozmawiałam z synem autora tej relacji, panem Jerzym Szapiro, który twierdzi, że ojciec nie mógł widzieć pochodu Korczaka.
} 
idzie, nie było salutowania (jak niektórzy opisują), na pewno nie było interwencji posłańców Judenratu - nikt do Korczaka nie podszedł. Nie było gestów, nie było śpiewu, nie było dumnie podniesionych głów, nie pamiętam, czy niósł ktoś sztandar Domu Sierot, mówią, że tak. Była straszliwa, zmęczona cisza. Korczak wlókł nogę za nogą, jakiś skurczony, mamlał coś od czasu do czasu do siebie. Gdy sobie tę scenę przypominam - rzadko mnie ona opuszcza - wydawało mi się, że słyszałem, że mamlał słowo »dlaczego« - byłem dość blisko, by usłyszeć. Ale to na pewno tylko wybryk mojej wyobraźni, w retrospekcji. Nie były to chwile filozoficznych refleksji; to były chwile tępej, milczącej rozpaczy bez granic, już bez pytań, na które nie ma odpowiedzi. Tych paru dorosłych z Domu Sierot, w tym Stefa (Wilczyńska), szło obok, jak ja lub za nim, dzieci początkowo czwórkami, potem jak popadło, w pomieszanych szeregach, gęsiego. Któreś z dzieci trzymało Korczaka za połę, może za rękę, szły jak w transie" 35 .

W podobnym tonie mówi o pochodzie Jerzy Lewiński36. W rozmowie z Ewą Koźmińską-Frejlak opowiada: „Wbrew różnym zapisom, między innymi temu sporządzonemu przez urzędnika żydowskiej gminy o nazwisku Remba, ów orszak był bardzo smutny, Korczak był przygnębiony, szedł o lasce. Za nim - Stefania Wilczyńska i te dzieci. Później, po wielu latach, napisał o tym Marek Rudnicki, który wówczas był młodym chłopcem i chodził na Umschlagplatz z chlebem z gminy. On widział ten pochód i widział, jak było"37.

Dochodzimy w ten sposób do kolejnego etapu ostatniej drogi Korczaka i dzieci. Wchodzą na Umschlagplatz, gdzie, jak mówi Remba, zostają posadzone na krańcu placu, pod murem ${ }^{38}$.

Pośrednio wynika z tego, że gdy weszli na plac, nie było tam jeszcze tłumów, skoro Remba mógł w jakiś sposób manewrować grupami wprowadzanych. Można tym samym przypuszczać, że grupa, która przyszła z małego getta, była jedną z pierwszych na Umschlagplatzu.

Jak długo mogło trwać oczekiwanie na wyjazd w nieznane? W czasie, kiedy Korczak wraz z dziećmi przebywał na Umschlagplatzu, prawdopodobnie ktoś już zaalarmował Gminę o wyprowadzeniu sierocińca i próbował zmienić tę decyzję. Anna Margolisowa pisze: „Natychmiast pobiegłam do szpitala, do dyrektora administracyjnego Kroszczora ${ }^{39}$. Powiedziałam mu, żeby poszedł do Gminy Żydowskiej, niech interweniują, niech ratują Korczaka"40. Czy był w Gminie ktoś jeszcze? Czy ktoś próbował ratować Korczaka i dzieci? Żydowski pisarz Jehoszua Perle powiedział w 1942 r.: „O tym, co miało miejsce na ulicy Siennej 16 dowiedziano się w międzyczasie w Judenracie. Zaczęto telefonować, biegać tu i tam, chciano pomóc. Ale

\footnotetext{
${ }^{35}$ Rozmowa z M. Rudnickim, loc. cit., s. 1-2.

${ }^{36}$ Jerzy Lewiński - wówczas funkcjonariusz Służby Porządkowej w getcie warszawskim.

${ }^{37}$ Rozmowa z J. Lewińskim, „Midrasz” 2005, nr 12, s. 31-32.

${ }^{38}$ Por. E. Ringelblum, op. cit., s. 607.

${ }^{39}$ Henryk Kroszczor - ówczesny dyrektor administracyjny Szpitala dla Dzieci im. Bersonów i Baumanów.

${ }^{40}$ Wspomnienie A. Margolis [w:] Wspomnienia o Januszu Korczaku, s. 285.
} 
kogo Gmina chciała uratować? Nie te 200 dzieci, oni chcieli uratować tylko Janusza Korczaka. Korczak podziękował panom z Judenratu, którzy wydawali Żydów na śmierć i udał się, krocząc na czele swoich dzieci, na punkt załadunkowy"41.

Na samym placu był już wspomniany Nachum Remba, ale był tam także i Marek Rudnicki, który wspomina: „A gdyśmy doszli do wejścia upał był obezwładniający, słońce prażyło niemiłosiernie. Korczak z dziećmi, Stefa i reszta personelu weszli na plac. Z miejsca, gdzie się zatrzymałem, z odległości jakichś 30 metrów widać było bocznicę i stojące na niej bydlęce wagony, niektóre już załadowane, niektóre otwarte ze szczelinami okienek zaszyte drutem kolczastym. Nad placem unosi się żrący oczy i szczypiący gardło wyziew chloru. Widzę na podłodze wagonu wapno, które ścieka, także z innych wagonów na tor"42.

Atmosfera Umschlagplatzu musiała robić na dzieciach przerażające wrażenie. Potworny tłum ludzi, sparaliżowanych strachem i niepewnych swojego losu, zamknięty teren, z którego nie było już ucieczki, śmierdzące i złowieszcze wagony dla bydła, które nijak miały się do obiecywanej wycieczki na wieś... Jeśli wolno nam snuć domysły, to można chyba sobie wyobrazić, że o ile wcześniej Korczak mógł jeszcze karmić dzieci iluzją wycieczki, o tyle w konfrontacji z tłumem Żydów na Umschlagplatzu ta opowieść coraz bardziej traciła na wiarygodności. Tak opisuje atmosferę Umschlagplatzu Edward Gadomski, który tego dnia był tam i widział Janusza Korczaka: „Tu na posesji szpitala, urządzili Niemcy ostatnią stację udręki nadludzkiej przed załadowywaniem do wagonów śmierci - do Treblinki. Tu oczekiwały pociągi o kilkudziesięciu wagonach każdy, wysypane karbidem i wapnem, tu obok pociągów stała kanalia niemiecka, która łącznie z kanalią spośród gettowej Służby Porządkowej za pomocą bata, pięści i wrzasku nadawała tempo, wlokącemu się nieprzerwanie jak gąsienica, pochodowi śmierci”³.

Rudnicki, który podczas Wielkiej Akcji pracował na Umschlagplatzu, tak pisze o atmosferze tam panującej: „Odkąd się zaczęła wielka deportacja, czyli likwidacja getta, 22 lipca, spędzano na ten plac, przy ulicy Stawki i Dzikiej codziennie dziesiątki tysięcy osób. Kłębiła się tam ogromna ciżba ludzi, w obłędnym zamęcie, zawodzeniu, jękach, ludzie wykrzykiwali imiona nawołując się wzajemnie, wielu padało z wycieńczenia, głodu i pragnienia i leżało pokotem. Wielu zażywało truciznę, całe rodziny we wspólnym uścisku. Nie było ustalonego porządku ładowania, niektóre grupy były na tym placu już parę dni i nocy. Ruchem kierował żydowski kierownik Umschlagplatzu, Szmerling i jego kohorta, wrzaskiem, biciem, kopniakami" ${ }^{44}$.

Oto inny jeszcze opis atmosfery Umschlagplatzu, atmosfery, w której przyszło Korczakowi i dzieciom czekać na wywózkę: „Dantejskie sceny działy się na Um-

${ }^{41}$ Wspomnienia J. Perle za: E. Dauzenroth, Janusz Korczak, życie dla dzieci, Kraków 2005, s. 69.

${ }^{42}$ Rozmowa z M. Rudnickim, loc. cit., s. 1-2.

${ }^{43}$ Wspomnienie E. Gadomskiego [w:] Wspomnienia o Januszu Korczaku, s. 287.

${ }^{44}$ Rozmowa z M. Rudnickim, loc. cit. 
schlagplatzu. Spędzano tam jak bydło po blisko 10000 osób dziennie. Wszystkie wyjścia były strzeżone przez uzbrojonych Niemców lub Ukraińców. Ludzie w obłędnej rozpaczy biegali bezradnie na różne strony łkając i lamentując. Czując podświadomie, że prowadzą ich na śmierć, miotali się w nieprzytomnej desperacji, jak myszy w klatce, szukając ratunku przed zagładą, szalejąc w śmiertelnej trwodze zostawiali na pastwę losu dzieci, rzucali plecaki, paczki, walizki. A sprawcy z drwiącym uśmiechem poganiali tę stłoczoną, desperującą masę, rycząc, bijąc pejczami i strzelając z karabinów i rewolwerów w tłum, ku wąskiemu przejściu prowadzącemu do wagonów i coraz ktoś padał przeszyty kulą. Był to makabryczny, nie dający się opisać widok"45.

Oczekiwanie na Umschlagplatzu mogło trwać do kilku godzin. Transporty odchodziły po południu, ale chyba nie da się ustalić jednej konkretnej godziny. Zależało to od wielu czynników, głównie od tego, czy zgromadzono już dostateczną liczbę osób do wywózki, jaka była przepustowość torów i jak sprawnie wprowadzano ludzi do wagonów. Remba chciał wykorzystać czas oczekiwania i w tych chwilach próbować interweniować w sprawie Korczaka. „Zaproponowałem Korczakowi, aby udał się ze mną do Gminy w celu skłonienia jej do podjęcia interwencji. Odmówił, nie chciał opuścić dzieci nawet na minutę"46.

Tutaj pojawia się znany wątek, jakoby Niemcy próbowali zostawić Korczaka, a wysłać do Treblinki tylko dzieci. Czy to możliwe, żeby Niemcy interweniowali? Czy byli to raczej Żydzi? Jak mogło to wyglądać? Wspomniany wcześniej Lewiński dementuje jednoznacznie te domniemania: „Pogłoska, że jeszcze na Umschlagplatzu jakiś niemiecki oficer ofiarował Korczakowi wolność jest również zmyśleniem. Żaden niemiecki oficer nigdy na Umschlagplatzu nie dał żadnemu Żydowi jakiejkolwiek wolności, nawet takiej oferty"47.

Jak już była mowa, atmosfera na Umschlagplatzu przypominała limbo, strwożonych ludzi tłoczono w wagonach, Korczak zaś prawdopodobnie był zaaferowany tym, by żadne dziecko się nie zgubiło. Ktoś pisze, że pomagał im wsiadać, ktoś inny, że wsiadł jako pierwszy. Czy w tym czasie jakiś Niemiec mógł podejść do niego i proponować mu zwolnienie? Jeśli tak, to kiedy? Czy przy wsiadaniu do wagonów, czy jeszcze podczas oczekiwania? Wiadomo, że niektórych udawało się z Umschlagplatzu „wyreklamować”. Pisze o tym między innymi Luba Blum-Bielicka, której uczennice-pielęgniarki udało się z Umschlagplatzu wyprowadzić. Podobną historię przytacza także Józef [Gitler] Barski, który opisuje sposób, w jaki udało mu się wyprowadzić z Umschlagplatzu bursę dla dziewcząt z kierowniczką Marią Rotblat. Po otrzymaniu listu z Umschlagplatzu poszedł interweniować do Szmerlinga. Ten nie wyraził zgody na zwolnienie zatrzymanych, ale pozwolił mu się skomunikować z komendantem placu, oficerem SS. Esesman również był przeciwny,

${ }^{45}$ Z pamiętnika Stanisława Sznapmana [w:] Pamiętniki z getta warszawskiego. Fragmenty i regesty, oprac. M. Grynberg, Warszawa 1988, s. 156.

${ }^{46}$ E. Ringelblum, op. cit., s. 607.

${ }^{47}$ Rozmowa z J. Lewińskim, loc. cit., s. 31. 
ale pod wpływem argumentów, że dziewczęta pracują w szopach, zatem - w myśl obowiązujących zarządzeń - wysiedleniu nie podlegają, ostatecznie pozwolił Barskiemu na wyprowadzenie dziewczą ${ }^{48}$.

Grupy Korczaka w ten sposób ocalić się nie dało; dzieci, oprócz kilku chłopców, w żadnym szopie nie pracowały i nie mogły być Niemcom do niczego przydatne. Nie było logicznych argumentów, które mogłyby przekonać komendanta obozu, by pozwolił dzieciom Korczaka zostać. Jemu prędzej, ze względu na jego autorytet, a także fakt, że był lekarzem.

Dzieci było około dwieście, wraz z nimi poszedł także personel Domu Sierot, około dwudziestu osób. Do wagonów jadących do Treblinki wtłaczano po około sto osób, można zatem przypuszczać, że Dom Sierot znalazł się co najmniej w dwóch wagonach. Z kim poszedł Korczak? Czy rozdzielili się ze Stefą Wilczyńską? Jak podzielono dzieci? Czy w ogóle był na to czas?

Pewnie więc wsiedli do wagonów i pojechali. Jak wyglądały wagony wewnątrz? Świadkowie mówią, że były wysypane wapnem i zdezynfekowane chlorem. Były to wagony bydlęce, przeznaczone do transportu zwierząt, głównie koni. Jan Mawult pisze, że na wagonach znajdowała się specyfikacja ich przeznaczenia: mianowicie 8 koni lub 40 ludzi $^{49}$. Te były jednak zupełnie nieprzystosowane do przewozu osób; pisze o tym Stanisław Sznapman. „Wagony były tak natłoczone, że ludzie stali jeden obok drugiego ściśnięci, bez możności poruszania się. Ławek do siedzenia nie było. W tych warunkach wszystkie plecaki, walizki, paczki, zaraz po wejściu zostały wyrzucone, by nie zajmowały miejsca. W przepełnionych w ten sposób wagonach, a zaplombowanych drzwiach i oknach, panował zaduch nie do zniesienia, nie było przy tym kropli wody"50.

Droga z Warszawy do Treblinki mogła trwać bardzo długo, biorąc pod uwagę zmiany załogi, postoje $\mathrm{w}$ lasach przed Treblinką, chwile wtaczania wagonów na rampę (zwykle w trzech turach: na rampie w Treblince mieściło się dwadzieścia wagonów, reszta czekała na swoją kolej. Transporty z Warszawy odchodziły zwykle po południu, jechały długo, całą noc, nierzadko jeszcze dłużej. W drodze pociąg zwalniał, przepuszczał inne transporty ${ }^{51}$.

W taki sposób opisuje tę drogę Samuel Zylbersztajn: „Wagony są strzeżone z obu stron. Na dachu leżą Ukraińcy. [...]W środku nocy mordercy urządzali strzelaninę przez ściany do wnętrza wagonów. Kto miał szczęście, tego trafiła kula, został zabity" 52 .

${ }^{48}$ Por. J. [Gitler] Barski, Przeżycia i wspomnienia z lat okupacji, Wrocław - Warszawa Kraków - Gdańsk - Łódź 1986, s. 31.

${ }^{49}$ Por. Z pamiętnika Jana Mawulta [w:] Pamiętniki z getta warszawskiego, s. 164.

${ }^{50}$ Z pamiętnika Stanisława Sznapmana [AŻIH, 302/198, k. 33-34] [w:] Pamiętniki z getta warszawskiego, s. 156.

${ }^{51} \mathrm{~W}$ normalnych warunkach taka podróż zajmuje około dwóch godzin.

52 Z pamiętnika Samuela Zylbersztajna [AŻIH, 302/109, k. 71-77] [w:] Pamiętniki z getta warszawskiego, s. 166. 
Franz Stangl, komendant obozu w Treblince, w rozmowie z Gittą Sereny mówi, że transporty zwykle przychodziły do Treblinki rano, około godziny ósmej ${ }^{53}$. Tego, co działo się z Korczakiem i dziećmi w Treblince, nie sposób zrekonstruować na podstawie świadectw, niemniej scenariusz był niezmienny. Pociąg zajeżdżał na bocznicę kolejową, tam wtaczano po około dwadzieścia wagonów i rozładowywano je. Niemcy do końca starali się zachować pozory i mimo że w pierwszej fazie akcji eksterminacyjnej nie było jeszcze rampy, z czasem zaczęto stylizować Treblinkę na prowincjonalną stacyjkę ${ }^{54}$. Były tam fikcyjne szyldy, strzałki, kasy biletowe. Nad rzekomym lazaretem powiewała flaga Czerwonego Krzyża. Tłumaczono przyjezdnym, że do tej pory niezbyt dobrze pracowali, ale teraz stworzy im się inne warunki i zmusi się ich do pracy na roli. Na początek jednak muszą przejść obowiązkową dezynfekcję i kąpiel. Oddzielano dzieci i kobiety od mężczyzn i prowadzono do kąpieli. Gitta Sereny dość dokładnie rekonstruuje drogę z placu, na którym przyjmowano transporty do komór gazowych. Pierwszym punktem był plac i rampa wyładowcza - to tam przeprowadzano pierwszą selekcję, tam także znajdował się fikcyjny szpital, gdzie zabijano strzałem starych i chorych, zamiast uśmiercać ich gazem; obok znajdowała się jeszcze rozbieralnia-barak, w którym ofiary rozbierały się do naga, kobietom obcinano włosy i badano, czy w ciele nie przechowują jakichś kosztowności. Stamtąd droga prowadziła już bezpośrednio do komory gazowej. Była to kilkumetrowa ścieżka z trzymetrowym płotem z drutu kolczastego po bokach, gęsto przeplatanym sosnowymi gałązkami, tak że nic nie można było przezeń zobaczyć. Nadzy ludzie przebiegali tą drogą w kierunku rzekomej łaźni - komór gazowych. Gdy instalacja do gazowania się psuła, co działo się nader często, musieli stać godzinami w oczekiwaniu na swoją kolej ${ }^{55}$. Gazowanie trwało $\mathrm{z}$ reguły od piętnastu do trzydziestu minut. Zdarzało się jednak, że silnik pracował wadliwie, co niewyobrażalnie wydłużało męki zamkniętych w komorze ludzi ${ }^{56}$. Z mężczyzn, których nie pognano od razu do komór gazowych, wybierano młodych i silnych, by jeszcze ich wykorzystać. Pozostałych czekała ta sama droga. Czasem zdarzało się, że nie wszyscy mieścili się do przepełnionych komór i wtedy musieli czekać obok. Słyszeli wtedy wszystko...

Z zachowanych przekazów wynika, że komory gazowe sprawiały wrażenie pomieszczeń z natryskami, jednakże do sitek pryszniców doprowadzone były przewody gazowe, którymi tłoczono tlenek węgla. Ofiary mogły nie zdawać sobie sprawy, że znalazły się w komorze gazowej. Następnie rozpoczynała się procedura gazowania. Na komendę: „woda” uruchamiano silnik czołgu i wpuszczano rurami spaliny do wypełnionych ludźmi pomieszczeń. Po egzekucji często okazywało się,

${ }^{53}$ Por. G. Sereny, W stronę ciemności. Rozmowy z komendantem Treblinki, przeł. J.K. Milencki, Warszawa 2002, s. 146.

${ }^{54}$ Por. J.A. Młynarczyk, Treblinka - obóz śmierci „akcji Reinhardt” [w:] Akcja Reinhardt. Zagłada Żydów w Generalnym Gubernatorstwie, red. D. Libionka, Warszawa 2004, s. 219.

${ }^{55}$ Por. G. Sereny, op. cit., s. 143.

${ }^{56}$ Por. J.A. Młynarczyk, op. cit., s. 221. 
że ciała ludzi były tak splątane, że nie dało się ich oddzielić od siebie i trzeba było polewać je wodą, by można je wyjąć pojedynczo ${ }^{57}$.

Dzieci w Treblince zabijano w tzw. „lazarecie”. Wejście do niego prowadziło przez budkę, na której powiewała flaga Czerwonego Krzyża. Z budki wchodziło się do poczekalni umeblowanej czerwonymi meblami, przypominającej prawdziwą poczekalnię szpitalną. Tu ludzie rozbierali się i szli na „badanie lekarskie”. Drzwi do gabinetu prowadziły prosto na deskę, na której strzelał do ludzi ukryty Niemiec lub Ukrainiec. Prosto z deski ofiary wpadały do leja, gdzie potem były palone. Czy dzieci Korczaka poszły do lazaretu? Czy wraz z pracownikami Domu Sierot zostały zapędzone do komór gazowych? Trudno to orzec, nie wiemy nic na temat ostatnich chwil Korczaka, dzieci i pracowników Domu Sierot w Treblince.

Jest jednak wstrząsająca relacja pracownika Treblinki, Żyda, który był wówczas zatrudniony przy opróżnianiu komór gazowych. W potwierdzonym notarialnie świadectwie pisze (zachowano pisownię oryginału): „Ja, Chaim Stajer, zamieszkały pod adresem: flat 3 - 200 Glen Ira Road, Elserwick w stanie Victoria w Australii stwierdzam, co następuje. Urodziłem się w Częstochowie w Polsce dnia 15go lipca 1909 roku. Zostałem zamknięty w ghetcie w Częstochowie na początku 1940go roku. Ghetto to zostało zlikwidowane około końca sierpnia 1940 go roku i wtedy zostałem wysłany do Treblinki. Gdy tam przybyłem zostałem oddzielony od mej rodziny i przydzielony do pracy w Sonderkommando, gdzie wpierw wprowadzono mnie do tak zwanego pierwszego lagru, a potem do totenlagru. Na początku września 1942, pamiętam, że był to zimny dzień, mój oddział pracował w tak zwanej środkowej komorze gazowej. Gdy otworzyliśmy drzwi od strony wnętrza obozu, przeznaczone do wyjmowania trupów ludzi, którzy wchodzili tam z drugiej strony, i gdy gazy się ulotniły, członek tego oddziału powiedział: »to są ludzie z Warszawy, tu jest dr. Janusz Korczak i jego sieroty«. Człowiek ten został przywieziony z Ghetta Warszawskiego. Ja słyszałem o doktorze Korczaku, lecz go nigdy przedtem nie widziałem. Obraz w komorze był następujący: mężczyzna stał pochylony z ramionami, był on jakby obłożony wielką ilością dzieci, które się go trzymały. Nie liczyłem dzieci, ale oceniam, że było tam około 200 do 300 dzieci. Zacząłem wyjmować dzieci wpierw, bo było niemożliwe dostać się do tego człowieka. Kapo zdzielił mnie po głowie pałką, bo kładłem tylko po dwoje dzieci na nosze, kazał mi brać po troje na raz" ${ }^{28}$.

Co o tym myśleć? Czy to możliwe, by Niemcy pozwolili wejść Korczakowi z dziećmi do komory gazowej? Jeśli tak, to w jaki sposób udało mu się uzyskać takie pozwolenie? Oznaczałoby to, że i dzieci, i on byli od razu przeznaczeni do zaprowadzenia do komór, ale tak czy inaczej powinni byli zostać wcześniej oddzieleni od kobiet i dziewczą - pracownic Domu Sierot, których było kilka. Oświadczenie Sztajera jest nieprawdopodobne - mimo wielu niedomówień, jesteśmy pewni, że Janusz

${ }^{57}$ Ibid., s. 225 .

${ }^{58}$ Relacja notarialna Chaima Stajera, złożona w 1980 r. w Australii. Kopia w Ośrodku Dokumentacji i Badań, Korczakianum, teczka 0091. 
Korczak zginął w pierwszych dniach sierpnia, a nie we wrześniu - nie wiadomo jednak, czy całkowicie niemożliwe. Jeśli okazałoby się prawdą, to pomimo całej okropności Treblinki możemy pocieszać się myślą, że dzieci Korczaka nie umierały samotnie... Wiadomo przecież, że Korczak nie poszedł z nimi, by je ratować; nie było to możliwe i on doskonale zdawał sobie z tego sprawę. Szedł z dziećmi, by drogę w nieznane uczynić jaśniejszą, by ulżyć im w chwilach ostatecznego cierpienia. Jak pisze Jeanne Hersch: „Dlaczego poszedł w końcu z tymi dziećmi... do pieca? Nie po to, aby zostać męczennikiem, nie aby pokazać, jaki jest nadzwyczajny, lecz całkiem po prostu, aby dzieci przeżyły mniej strachu. Mniej strachu"59.

Jednak mimo tej okrutnej prawdy, którą wszyscy znali, już w 1943 r. obiegła Warszawę wiadomość, że Korczak nie zginął w Treblince. Wagon, którym jechał, miał się podobno odczepić i nie dowieźć dzieci do obozu zagłady. Podobno widziano, jak „Stary Doktór wędrował z gromadką dzieci od wsi do wsi” ${ }^{60}$.

Dzieci opuściły swój Dom Sierot 5 sierpnia 1942 roku w godzinach porannych. Trzem chłopcom i wychowawcy, pracującym wówczas na placówce po stronie „aryjskiej”, udało się ujść z życiem, jako że w czasie blokady budynku byli poza granicami getta i nie zostali zaprowadzeni na Umschlagplatz. Z relacji Miszy Wróblewskiego wynika, że przeżyli: Jakubek Bojm, niewymienieni z nazwiska Maniuś, Dawidek i on sam ${ }^{61}$.

Sam budynek Domu Sierot cudem ocalał z pożogi wojennej. Nie był nawet jakoś szczególnie zniszczony. Stefania Podhorska-Okołów wspomina nawet, że po wojnie odbywały się tam przedstawienia kukiełkowe ${ }^{62}$, co byłoby dowodem na to, że budynek nie tylko zewnętrznie, ale i wewnętrznie zachował się w niezłym stanie. Jest to zrozumiałe, jako że już w połowie sierpnia 1942 r. ten teren został wyłączony ze szczątkowego getta. Jego losy szczegółowe nie są niestety znane. Na tym obszarze nie toczyły się także walki podczas powstania w kwietniu 1943 r., nie należał więc do miejsc systematycznie przez Niemców plądrowanych i niszczonych. Dawny sierociniec został zburzony dopiero podczas budowy Pałacu Kultury i Nauki. Nie był jedynym budynkiem, który został wtedy zrównany z ziemią: zburzono ponad sto domów i zlikwidowano duże fragmenty zabudowy siedmiu ulic ${ }^{63}$. Dziś na miejscu Domu Sierot znajduje się część Teatru Lalka i chodnik. Od niedawna stoi tam także pomnik upamiętniający Korczaka i jego dzieci.

\section{Słowa kluczowe}

Janusz Korczak, dzieci, getto warszawskie, Umschlagplatz, opieka społeczna

\footnotetext{
${ }^{59}$ J. Hersch, Wykłady wiedeńskie, za: E. Dauzenroth, s. 83.

${ }^{60}$ Por. K. Mórawski, Kartki z dziejów Żydów warszawskich, Warszawa 1993, s. 131.

${ }^{61}$ Por. Ośrodek Dokumentacji i Badań Korczakianum, teczka 0628, Wspomnienie Miszy Wróblewskiego.

62 Por. S. Podhorska-Okołów, Warszawa mojego dzieciństwa, Warszawa 1995, s. 86.

${ }^{63}$ Por. A. Kotańska, Warszawa wczoraj i dziś, Warszawa 2004, s. 197.
} 
Abstract

The article is an attempt at reconstructing the last road of the inhabitants of Janusz Korczak's Orphanage to the Umschlagplatz. It is mainly based on testimonials of the witnesses and analysis of the then-realities of the Warsaw Ghetto. Its aim is to establish the most probable version of the events and to eliminate products of imagination existing in collective memory until today.

\section{Key words}

Janusz Korczak, children, Warsaw Ghetto, Umschlagplatz, welfare 